\title{
RESEARCH OF THE STRUCTURE OF LEARNING MOTIVATION AS A PREREQUISITE FOR FORMATION OF COMPETENCES OF THE FUTURE ECOLOGIST
}

\author{
Sergey Kravchenko ${ }^{1}$ \\ ${ }^{I}$ Ph.D. (Pedagogy), teacher, Dnieper Vocational College of Engineering and Pedagogy of UDKHTU, \\ Kamyanske, Ukraine, e-mail: kravchenko_ikollege@ukr.net, ORCID: https://orcid.org/0000-0001-9008- \\ 8816
}

Abstract. This article considers the problem of insufficient motivation to acquire professional competencies by environmental students. Of course, the study of motivation for learning is always a topical issue. One of the priority areas of reforming modern education is to achieve a new level in the training of highly qualified specialists, including environmentalists. Proper preparation for teaching is now considered an important factor in improving the quality of education and, as a result, accelerating the socio-economic development of society. Analysis of the state of theoretical and experimental development of the problem of formation and development of motives, allows to determine the main directions in which modern research is carried out. The current stage of development of theory and practice of training future ecologists is characterized by an intensive search for ways to form and develop motives for future teaching, as one of the conditions for forming the foundations of their pedagogical skills. education. The issue of research of the structure of motivation of the student-ecologist to the choice of profession and educational-scientific activity in the educational institution as conditions of formation of professional competences is actualized. The ideas of different scientists on the definition of motivation and scope are studied. Motivation is recognized as a prerequisite and condition of activity, including training. The results of research of motives of choice of ecological specialty by students of profile educational institutions, training and realization of research activity are resulted. The low level of motivation for educational activity, the predominance of romantic and mercantile motives in choosing a profession, insufficient awareness of the need to acquire quality knowledge and research qualities. The problem of development of receptions and methods of strengthening of educational motivation of future experts in ecology is defined.

Keywords: motivation, motive, educational motivation, motivation for research activity, future ecologists.

JEL Classification: I0; I20

Formulas: 0; fig.: 3; tabl.: 0; bibl.: 9

Introduction. The main purpose of the Ukrainian vocational school is to create conditions for the possibility of acquiring a certain list of competencies necessary for successful production activities. Future ecologists are required to skillfully apply the acquired knowledge, skills and abilities in specific production and technological situations, creative thinking, self-promotion and implementation of individual environmental projects, as well as confident orientation in related fields of knowledge.

The scientific and pedagogical community pays enough attention to the study of factors and conditions that affect the formation of a competent ecologist. The study of the structure of motivation for educational and scientific activities as a condition for the formation of a competent specialist in ecology remains a topical issue.

Literature Review. To study this problem, a theoretical analysis was performed and literature sources on this issue were systematized. Foreign and domestic scientists D. McClelland, D. Atkinson, G. Heckhausen, G. Kelly, Y. Rotter, 
K. Rogers, R. May, A. N. Leontiev and others. In the psychological and pedagogical literature, the motivational aspect of learning was given due attention by S. L. Rubinstein, G. C. Kostyuk, V. S. Merlin, V. O. Sukhomlinsky, M. I Alekseeva, I. O. Tit and others.

Scientists have long paid due attention to the role of motivation in carrying out certain activities. As early as the first half of the last century, the American psychologist N. Murrau defined motivation as a person's need to achieve results in a certain job, the desire to overcome obstacles, the driving force in trying to do something complex faster and better [1].

Motivation by A. Markova was singled out as a sphere of behavior, which includes motives, goals, emotions and the ability to learn, as an incentive to activity associated with meeting the needs of the subject, his feelings, interests, habits. Motivation can consist of a number of different motives [2, p. 100].

T. Blank noted that "motivation is an incentive to action that increases human activity, determines its interests, needs, aspirations" [3, p. 2].

In turn, this concept of T. Dudar was defined as an internal motivating cause, an actualized need that motivates a person to certain actions and deeds, as a result of which the need can be satisfied [4, p. 162], and O. Bartkiv - a generator of human creativity, which encourages them to activity [5].

A. Fonaryov considered motives as motivating causes of human activity [6, p. 74]. In his opinion, they play an important role in directing and organizing the process of cognition, the formation of a lasting interest of students in learning.

G. Schukina claimed about the significant role of motivation in ensuring high activity of educational activities [7, p. 64] and O. Sushentsev [8], who determined that the most important motive for successful cognitive activity is cognitive interest.

The content of education of the future ecologist is reflected in the curriculum. However, T. Sulima notes that the motivation to study is influenced, in addition to the specifics of educational activities and educational content, features of the educational process, psychological and qualitative characteristics of students (age, gender, intellectual development, abilities, self-esteem), specifics of teaching disciplines. The researcher noted that constant motivation for learning activities can be the key to successful self-education, self-organization, self-control, perseverance in the study of educational material $[9$, p. 434].

The analysis of theoretical sources allows us to conclude that the presence of proper motivation to acquire the profession should be considered as a prerequisite and condition for the formation of a student ecologist as a competent specialist.

Aims. The purpose of the article is to research of the structure of educational motivation of students-ecologists to master the chosen specialty during the period of education.

Methods. Determining the structure of motives for environmental education was carried out during 2016-2018. The study involved 406 students majoring in "Ecology" and 20 teachers of natural sciences at five colleges in Kyiv, Dnipro, Myrhorod, Poltava region, Kamjanske and the city of Kryvyi Rih, Dnipropetrovsk region. The data were obtained by observing the educational activities of future 
environmentalists, questionnaires of students, questionnaires and interviews of teachers involved in the study. The representativeness of the sample size allowed to draw reliable conclusions.

Results. Analysis of the data shows that $66.6 \%$ of respondents identified the priority factors of choosing a profession advice from others, which indicates the dominance of personal ignorance of the choice. Interest in the content of the profession of ecologist has become a priority for less than half of students (46.5\%). $43.8 \%$ of respondents preferred the attractiveness of career prospects (these are indicators of conscious choice and personal desire for change for the better). Fascination with external features of the profession (prestige, high pay, comfortable working conditions, popularity of the profession, etc.) became relevant for $37.3 \%$ of respondents, and educational factors - only for $9.2 \%$.

This dynamics coincides in the studied educational institutions with small differences. Generalized data of the whole group of respondents are shown in Fig. 1.
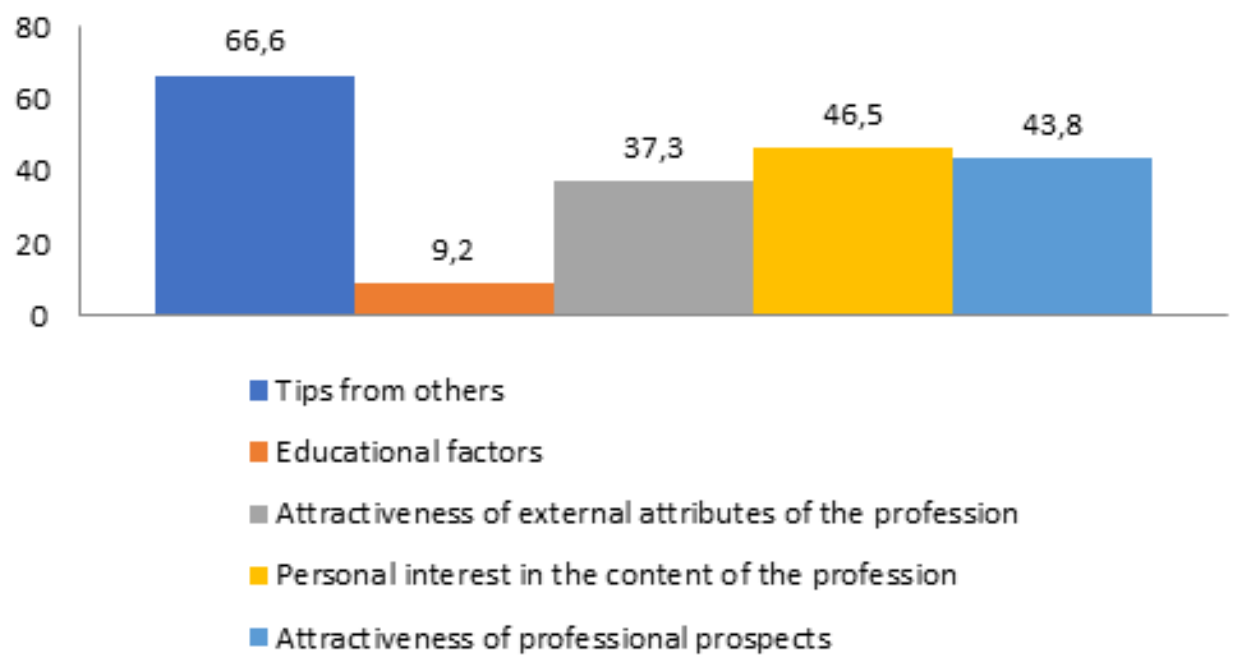

\section{Figure 1. Analysis of factors of choice of profession by students-ecologists, $\%$.}

Simultaneously with the study of the factors of choosing a profession, these respondents studied the motives for mastering the profession. It should be noted that the majority of respondents identified several motives as a priority.

The students of the whole sample identified the realization of their own inclinations and priorities $(61.0 \%)$ and the desire to benefit society with their professional activities (53.7\%) as priority motives for mastering the profession, which, in our opinion, indicates the predominance of a fairly mature and realistic attitude to the profession of ecologist chosen by these students. But among these respondents, a significant proportion remained naive romantics with an immature choice of future professional activity, who chose to receive high income $(41.5 \%)$ and achieve a high social status $(41.7 \%)$.

It should be noted that more than a third of respondents $(38.2 \%)$ consider the provision of their own high qualification to be the leading motive for learning. Naive and romantic motives also prevail among students, which indicate a fascination with the external attributes of the profession: the desire to benefit society through their 
professional activities (53.7\%) and the achievement of a high social status (41.5\%). But college education, as a basis for further personal and professional development, which indicates a vision of further prospects for professional growth and for the realization of their own aptitudes and priorities, is present in almost half of students (43.5\%). These data indicate a lack of professional motivation for learning among students, which, in turn, may lead to insufficient interest in research. The lowest rank was occupied by mercantile motives: a good job after training (23.9\%) and a sense of recognition of their professional advantages among others (11.8\%).

Summary data of the whole group of respondents are shown in Fig. 2.

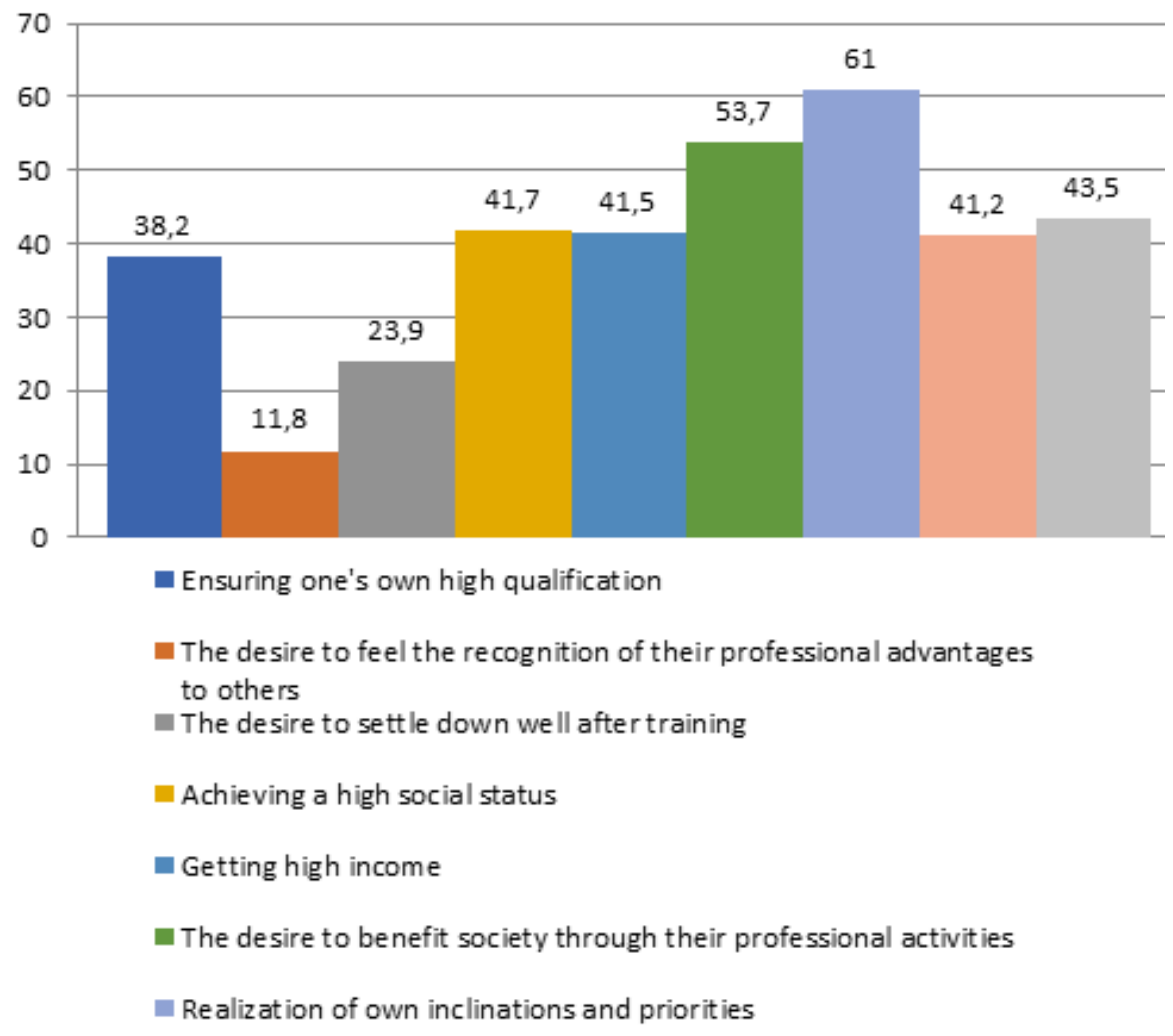

\section{Figure 2. Analysis of motives for mastering the profession by environmental students, $\%$.}

Thus, it was found that a significant number of respondents do not realize the nature of professional training and do not perceive college as the first step, the basis for further personal and professional development (only 43.5\%), which does not meet modern requirements of the labor market and professional environment. It is significant that students of all educational institutions equally underestimate the importance of such motives as the social usefulness of their professional activities and gaining professional authority, professional recognition of their personality, which indicates the lack of social orientation of their own training and the dominance of purely selfish motives.

The survey of students allowed to rank the motives that motivate environmentalists to engage in research activities. Summary data of the whole group of respondents are shown in Fig. 3. 


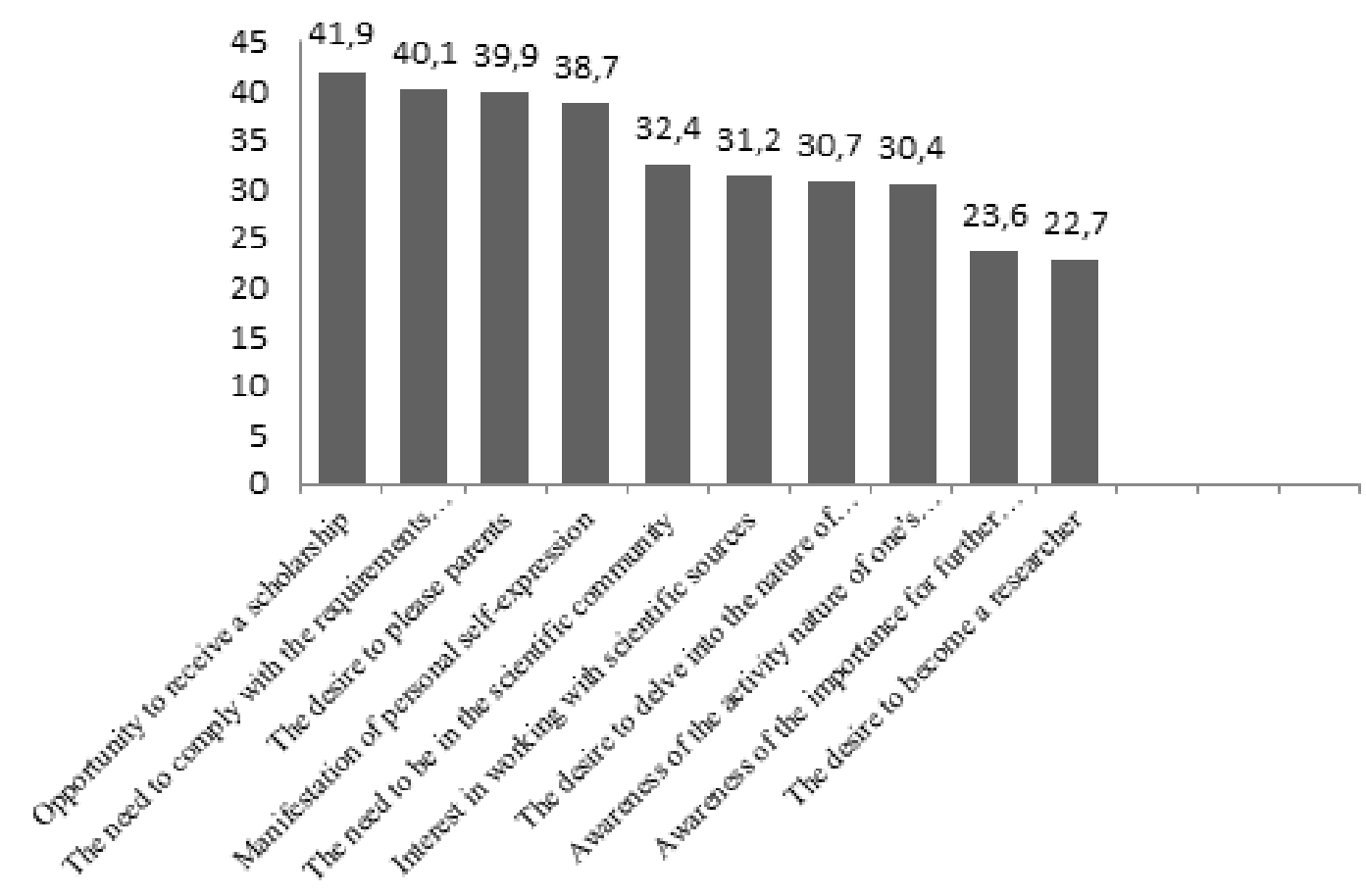

Figure 3. Analysis of motives that motivate students to research, $\%$.

Based on the results, we can determine that the dominant motives for involving students in research activities are: the opportunity to receive a scholarship (41.9\%); the need to comply with the requirements of teachers $(40.1 \%)$; desire to please parents (39.9\%); manifestation of personal self-expression (38.7\%).

It should be noted that these motives for involvement in research activities, which are important for the surveyed students, are defined in the range from $38.7 \%$ to $41.9 \%$.

It is also necessary to have a significant proportion of students who have a lack of understanding of the importance of mastering research skills, they demonstrate a model of behavior acquired in the context of secondary school. That is why the last places in the 10 most important motives were "Awareness of the importance for further professional activity" (23.6\%) and "The desire to become a researcher" $(22.7 \%)$.

Discussion. The results of research show that almost half of the studentsecologists have chosen this specialty situationally and therefore they do not see prospects in the future as specialists. It should be noted that the conscious choice of profession, the presence of appropriate motivation for learning, research and interest in studying disciplines determine the need of future environmentalists to engage in educational activities, in accordance with the objectives and goals of the educational process, and successfully complete it.

According to the results of student surveys, analysis of interviews with teachers involved in the study of educational institutions, there is always a significant share of freshmen who unknowingly, accidentally or due to a certain economic situation chose the profession of ecologist. As a result, such students are insufficiently motivated to learn and master professional skills. Also, most freshmen do not have sufficient 
research skills, abilities and experience, they are not familiar with the methodology or practice of research. The vast majority of junior students are not able to productively organize their process of acquiring knowledge, work systematically, independently and persistently, which may be explained by insufficient formation of these qualities in secondary schools. It should also be noted that most students who study in colleges, not without the "help" of teachers tend to reproductive activities. This phenomenon is the reason why students do not gain experience of productive, creative work. The traditional problem is the lack of new textbooks and manuals in educational institutions, which represent the problematic presentation of educational material, and the possibility of using digital media and the use of Internet resources in the educational process is mostly based on enthusiastic teachers and so on.

Conclusion. The results of this study are of a recommendatory nature for the pedagogical community of educational institutions that work with students majoring in "Ecology". It is worth paying more attention to the implementation of techniques and tools to strengthen the motivation to learn the content of professional activities, which will contribute to the realization of students-ecologists of their abilities, the disclosure of their creative potential and effective professional implementation.

Based on the results obtained, we must conclude that assigning the student the role of performer, the one who must act according to a clearly defined algorithm, does not contribute to the development of creative potential of the individual and forms a utilitarian type of their worldview. In addition, a significant number of future environmentalists are not yet aware of the importance for future professional activities of mastering thorough knowledge, skills, abilities, appropriate motivation and experience, typical of a competent specialist.

The prospect of further research we see in the development of methods and techniques to increase student motivation for teaching, research and professional activities, research and analysis of the effectiveness of their impact on the consciousness and effectiveness of educational achievements of future environmentalists.

\section{References:}

1. Murray H.A. (1938). Explanations in personality. N.Y. : Oxford Univ. Press, 761 p.

2. Markova A.K. (1993). Psykholohyia truda uchytelia: knyha dlia uchytelia [Psychology of teacher work: a book for teachers. Moscow: Enlightenment]. Moskva: Prosveshchenye. 192 s. [In Russia]

3. Blank T.V. (2009). Formuvannia pozytyvnoi motyvatsii yak faktoru uspikhu navchalnoi diialnosti molodshykh shkoliariv. Pochatkove navchannia ta vykhovannia [Formation of positive motivation as a factor of success of educational activity of junior schoolchildren. Primary education and upbringing.]. Kharkiv: Osnova, № 16/18. S. 2-9. [in Ukraine]

4. Dudar T.H., Melnychenko V.V. (2009). Innovatsiinyi menedzhment: navch. Posib [Innovation management: textbook. way.]. Kyiv: Tsentr uchbovoi literatury. 256 s. [in Ukraine]

5. Bartkiv O. (2010). Hotovnist pedahoha do innovatsiinoi profesiinoi diialnosti [Readiness of the teacher for innovative professional activity]. Problemy pidhotovky suchasnoho vchytelia, № 1. S. 52-58. [in Ukraine]

6. Fonarov A.R. (2004). Rozvytok osobystosti v protsesi profesionalizatsii [Personality development in the process of professionalization]. Pytannia psykholohii, № 6. S. 72-83. [in Ukraine]

7. Shchukyna H.Y. (1986). Rol deiatelnosty v uchebnom protsesse: knyha dlia uchytelia [The role of activities in the learning process: a book for teachers]. Moskva: Prosveshchenye. 144 s. [In Russia]

8. Sushentsev O.Ie. (2010). Pedahohichni umovy aktyvizatsii piznavalnoi diialnosti uchniv osnovnoi shkoly na urokakh trudovoho navchannia[Pedagogical conditions for activating the cognitive activity of primary school students in the lessons of labor training]. In-t pedahohiky APN Ukrainy. K. 24 s. [in Ukraine] 
9. Sulyma T.S. (2012). Formuvannia tvorchykh pedahohichnykh umin yak skladovoi profesiinoi kompetentnosti maibutnikh pedahohiv profesiinoho navchannia [Formation of creative pedagogical skills as a component of professional competence of future teachers of professional training]. Suchasni informatsiini tekhnolohii ta innovatsiini metodyky navchannia u pidhotovtsi fakhivtsiv: metodolohiia, teoriia, dosvid, problemy, Vyp. 32. S. 432-436. [in Ukraine]

Received: November 21, 2020 Approved: December 15, 2020 